IRSH 56 (20I I), Special Issue, pp. 45-67 doi:I0.1017/S002085901 1000538 (C) 20 I I Internationaal Instituut voor Sociale Geschiedenis

\title{
Labour Ideologies and Women in the Northern Netherlands, c.I500-I $800^{*}$
}

\author{
A RIA D NE SCHMIDT \\ Institute for History, Economic and Social History, \\ Leiden University \\ E-mail: a.schmidt@hum.leidenuniv.nl
}

\begin{abstract}
Summary: The ideology of domesticity that identified women with a domestic role became more articulated in north-western Europe throughout the early modern period. At the same time, perceptions of work changed and a new appraisal of labour emerged. These seemingly contradictory tendencies prompt the question how women fitted in with the ideology of work. This article discusses common notions of the economic role of women as they emerged from the debates on women, gender relations, and work; how these notions were translated into practical advice in conduct literature; and with what norms women were confronted in everyday life. It appears that work was valued positively for both women and men. Women's involvement in remunerated work was not considered problematic. There was a dividing line, however, and that was drawn between work within the home, which was deemed women's work, and work outside the home, which was deemed men's work. In practice, a differentiation was made between social groups; women who lacked income from capital were supposed to earn their living from work.
\end{abstract}

\section{INTRODUCTION}

The historiography of European women's work has long been dominated by the marginalization thesis. It was widely assumed that the opportunities for women to work were restricted owing to the rise of capitalism, the ideology of the separation of spheres, and the growing cult of domesticity. With production and consumption becoming separated, growing proletarianization, and the concentration of production under one roof, production moved outside the household to factories, depriving women of the opportunity to carry out the economically rewarding,

* The research conducted for this article was carried out as part of the "Women's Work in the Northern Netherlands in the Early Modern Period (c.1500-18 Is)" project, financed by the Friends of the International Institute of Social History and the Netherlands Organization for Scientific Research (NWO). I am grateful to Manon van der Heijden, Lex Heerma van Voss, and Jan Lucassen for their comments on earlier versions. 
skilled, and high-status work they had been involved in when production had been home-based. The poorer women were condemned to work hard in factories for low wages. The more well-to-do were confined to the home, while their husbands, as family breadwinners, went out to earn a living. ${ }^{\mathrm{I}}$

The ideology of the separate spheres that divided the world into a public domain, for men, and the private domestic sphere, the domain of women, became more sharply articulated in the eighteenth century. It grew to become the dominant ideology regarding the proper place of women in the nineteenth century and became a central element in the creation of middleclass identity. ${ }^{2}$ The paradigm of the separate spheres has been much criticized. Sceptics have argued that the public-private dichotomy is inadequate as an analytical framework as the distinction between the two spheres was often unclear and does not capture actual female experiences. ${ }^{3}$ Yet many historians do agree that gender norms narrowed during the early modern period, and, at least in the prescriptive literature, women were unmistakably and increasingly identified with a domestic role. ${ }^{4}$

Dutch society is said to have played a pioneering role in the development of the concept of middle-class domesticity. ${ }^{5}$ Both the specific social and economic developments and changes on the religious front were of influence. As elsewhere in post-Reformation north-western Europe, the Protestant elevation of marriage emphasized and celebrated the role of women as mothers and housewives. ${ }^{6}$ More exceptional, compared with other European countries, were its early urbanization, economic specialization, and emergence of a labour market, and the coincidence of those three factors. Combined with the absence of a strong nobility, the social dominance of the middle class, and the rise of the bourgeois family in the seventeenth century, these developments stimulated the emergence of an

I. Alice Clark, Working Life of Women in the Seventeenth Century (London, 1992 [1919]), was influential in this debate. See also Louise Tilly and Joan Scott, Women, Work and Family (New York, 1978); Merry E. Wiesner, Working Women in Renaissance Germany (New Brunswick, NJ, 1986); Bridget Hill, Women, Work and Sexual Politics in Eighteenth-Century England (Oxford, 1989); and Heide Wunder, Er ist die Sonn, sie ist der Mond. Frawen in der Frühen Neuzeit (Munich, 1992).

2. Leonore Davidoff and Catherine Hall, Family Fortunes: Men and Women of the English Middle Class, $1780-1850$ (Chicago, IL, I987).

3. Amanda Vickery, "Golden Age to Separate Spheres? A Review of the Categories and Chronology of English Women's History", The Historical Journal, 36 (1993), pp. 383-414; Dorothee Sturkenboom, Spectators van Hartstocht: Sekse en Emotionele Cultuur in de Achttiende Eeuw (Hilversum, 1998), p. 333.

4. Deborah Simonton, A History of European Women's Work: 1700 to the Present (Abingdon 1998), pp. I 3-I4; Sturkenboom, Spectators van Hartstocht, p. 334.

5. Jan de Vries and Ad van der Woude, The First Modern Economy: Success, Failure, and Perseverance of the Dutch Economy, I500-I8Is (Cambridge, I997), p. 605.

6. Merry E. Wiesner, Women and Gender in Early Modern Europe (Cambridge, 2000), p. 28. 
ideal that divided the public from the private sphere and assigned the task of earning an income to men and household activities to women.

Furthermore, the relatively high standard of living during the Golden Age of the Dutch Republic enabled the early practical realization of this dominant ideology and led to an early withdrawal of women from the labour market. ${ }^{7}$ Work inside the home must have occupied women earlier than in other countries. "Standards of domestic comfort rose higher and spread further down the social scale than elsewhere before the nineteenth century", Jan de Vries and Ad van der Woude concluded. ${ }^{8}$

At the same time, the early modern period has been characterized as a turning point in the perception of labour. Traditionally, manual labour was seen as degrading, but in the late Middle Ages attitudes towards work changed and a new appraisal of labour emerged. ${ }^{9}$ Again, the northern Netherlands represents an interesting case. Calvinism was said to have encouraged a new work ethic that was characterized by diligence, thrift, and self-discipline. ${ }^{10}$ According to economic historians, profound socioeconomic changes led to an intensification of labour and to work being highly esteemed. ${ }^{\text {II }}$ Work became increasingly perceived as beneficial to both the individual and to society as a whole. There was, moreover, a growing awareness of the economic importance of work, and work was also increasingly linked with consumption. ${ }^{\mathrm{I} 2}$ The emergence of new industrious behaviour, and especially the increased industriousness of women, forms a key element in De Vries's theory on the economic transformation of the early modern period. To be able to purchase new consumer goods, married women and children especially changed how they allocated their time, devoting less to leisure and household production and more to income-earning work. ${ }^{\mathrm{I}}$

7. Hettie A. Pott-Buter, Facts and Fairy Tales about Female Labor, Family and Fertility: A Seven Country Comparison (Amsterdam, 1997), pp. 66-67, 282-287; De Vries and Van der Woude, First Modern Economy, pp. 604-605.

8. De Vries and Van der Woude, First Modern Economy, p. 605.

9. Diana Wood, Medieval Economic Thought (Cambridge, 2002), pp. 52-53.

I0. Catharina Lis and Josef Ehmer, "Introduction: Historical Studies in Perceptions of Work", in Josef Ehmer and Catharina Lis (eds), The Idea of Work in Europe from Antiquity to Modern Times (Farnham, 2009), pp. I-30, 9.

I I. Ibid., p. I 8.

I2. Robert Jütte, Poverty and Deviance in Early Modern Europe (Cambridge, 1994), p. 198; James R. Farr, Artisans in Europe 1300-1914 (Cambridge, 2000), pp. I 5-20; Thomas Buchner, "Perceptions of Work in Early Modern Economic Thought: Dutch Mercantilism and Central European Cameralism in Comparative Perspective", in Ehmer and Lis, The Idea of Work in Europe, pp. 19I-2I3, $2 \mathrm{II}$.

13. Jan de Vries, "Between Purchasing Power and the World of Goods: Understanding the Household Economy in Early Modern Europe", in R. Porter and J. Brewer (eds), Consumption and the World of Goods (London, 1993), pp. 177-205; Jan de Vries, The Industrious Revolution: Consumer Behavior and the Household Economy, I650 to the Present (Cambridge, 2008), pp. 82, 108. 
There seems to be a discrepancy between the narrowing norms for women and the increasingly positive evaluation of work. How did women fit in with the ideology of work? This article discusses common notions of the economic role of women as they emerged from the sixteenth- and seventeenth-century debates on women, gender relations, and work. It examines how these notions were translated into practical advice in conduct literature, household guides, and marriage manuals. The question to what extent ideology affected the actual labour practices of women lies beyond the scope of our study, though the last section examines the gender norms with which women were confronted in everyday life.

\section{IDEAS ON WOMEN}

Work, women, and marriage were the subject of lively debates in the early modern period. Those often intertwined debates shaped the context in which norms about women and work were set and contributed to a growing interest in such matters. ${ }^{\mathrm{I}}$

A large body of literature on women and gender differences was published in the context of the Querrelle des femmes, the international Renaissance literary debate on the question of which sex was superior. ${ }^{15}$ Also, in the late fifteenth and sixteenth centuries the pictorial tradition of stories concerning the "power of women", disseminated through the arts and literature, became a popular theme in Dutch art. The women in these stories, of whom Eve, Delilah, and Phyllis, seducing Adam, Samson, and Aristotle respectively, are probably the best known, cunningly discredit men. The stories served an exemplary function, warned about the dangers of women, tried to preserve men from foolish behaviour, and pointed to the importance of self-control as a male virtue. ${ }^{16}$ Around the same time, the theme of reversed gender roles also gained popularity. The ridiculing of reversed gender roles in comic literature and visual representations aimed to emphasize male authority. Women and men each had their own tasks and responsibilities, and the popular theme taught them that they should stick to this "natural" allocation of those tasks and responsibilities. ${ }^{17}$

I4. Marijke Spies, "Women and Seventeenth-Century Dutch Literature", Dutch Crossing, I9 (1995), p. 3; Yvonne Bleyerveld, Hoe Bedriechlijck dat die Vrowwen zijn: Vrouwenlisten in de Beeldende Kunst van de Nederlanden, circa 1350-1650 (Leiden, 2000), p. I2; Els Kloek, Vrouw des huizes. Een cultuurgeschiedenis van de Hollandse huisvrouw (Amsterdam, 2009), pp. 16-19. I 5. Wiesner, Women and Gender in Early Modern Europe, p. 20; Spies, "Women and SeventeenthCentury Dutch Literature”, pp. 8-9; Bleyerveld, Hoe Bedriechlijck dat die Vrouwen zijn, p. 21 5; S. Veld, "Tot lof van vrouwen? Retorica, sekse en macht in paradoxale vrouwenloven in de Nederlandse letterkunde (I 578-I662)" (unpublished Ph.D. thesis, Utrecht University, 2005), pp. IO-I I, I6, 253. I6. Bleyerveld, Hoe Bedriechlijck dat die Vrouwen zijn, pp. 296-297.

17. Lène Dresen-Coenders, Helse en Hemelse Vrowwenmacht omstreeks I500 (Nijmegen, I988), pp. $3 \mathrm{I}-38$. 
The popularity of the theme of reversed gender roles was part of the growing interest in gender relations, an interest linked to the profound socio-economic changes in this period, and more specifically to the emergence of a new division of labour from the late Middle Ages. ${ }^{18}$ With the emergence of labour markets, old production forms and labour relations were replaced by new ones. Tasks had to be redefined and became more strictly divided between women and men; women were assigned the household and men the world of work. The gender hierarchy propagated in books of instruction and in visual representations are said to have supported the tendency of the urban bourgeois to exclude women from the urban labour market. ${ }^{19}$

Changes on the religious front also contributed to the heightened interest in what were deemed proper roles for women. The Reformation rejected the superiority of celibacy and defended matrimony. New norms had to be set, specified, and legitimized. Marriage became the standard, mutual help and companionship the aim, and in wedlock men and women were assigned specific, gendered roles. Reformists emphasized the "natural" differences between women and men, and propagated a gender-specific allocation of tasks. ${ }^{20}$

It is difficult to assess the precise effects of Protestantism on the position of women. New norms cannot simply be qualified as positive or negative, as much depended on whether such norms were actually enforced. Historians have pointed out that there were many similarities between Protestant and Catholics ideals and that the assignment of household tasks to women was a constant factor that transcended religious boundaries. ${ }^{21}$ However, even though the Reformation did not engender a completely new gender ideology, the religious changes of the sixteenth century certainly did intensify the debate on gender roles.

\section{IDEAS ON WORK}

Obviously, norms concerning women and work were influenced not only by ideas about women, but also by ideologies about work. In the early modern northern Netherlands work was valued positively, and this high

I8. Ibid., pp. 34-35; idem, "De machtsbalans tussen man en vrouw in het vroegmoderne gezin", in Harry Peeters, Lène Dresen-Coenders, and Ton Brandenbarg (eds), Vijf eeuwen gezinsleven: Liefde, buwelijk en opvoeding in Nederland (Nijmegen, 1988), pp. 57-98, 58; Herman Pleij, "Wie wordt er bang voor het Boze Wijf? Vrouwenhaat in de Middeleeuwen", De revisor, 4:6 (1977), pp. 38-42, 41. For an overview of this debate see Bleyerveld, Hoe Bedriechlijck dat die Vrouwen zijn, pp. $25 \mathrm{I}-252$. 19. Dresen-Coenders, "De machtsbalans", p. 58. See also Bleyerveld, Hoe Bedriechlijck dat die Vrouwen zijn, p. 253.

20. M.J. Gunning, Gewaande Rechten: Het Denken over Vrouwen en Gelijkheid van Thomas van Aquino tot de Bataafsche Constitutie (Zwolle, I991), pp. 79, 97.

2. Wiesner, Women and Gender in Early Modern Europe, pp. 26, 29. 
esteem is often related to the spread of Calvinism. Weber asserted that the Calvinist doctrine of predestination contributed to the development of a new work ethic that emphasized the necessity for hard work and ultimately contributed to the development of capitalism. ${ }^{22}$ This causality has become the subject of debate in the historiography on religion and work ideologies. ${ }^{23}$ Many scholars have reversed the theory and claimed that changing economic and social structures drove ideological changes, and that the capitalist mentality engendered a new economic mentality, the Protestant "work ethic". ${ }^{24}$ As Lis and Ehmer have shown, there is a broad consensus that the intensification of labour and the greater esteem in which work was held were caused in part by profound socio-economic changes, such as the transformation of agrarian class structures, the processes of urbanization, proletarianization, and social differentiation with an ongoing stratification of the population. ${ }^{25}$ These factors are also very plausible explanations for the emergence of a new work ethic in the Dutch Republic.

Despite the debates, there seems to be agreement about the existence of a particular work ethic in early modern western Europe. ${ }^{26}$ This work ethic was further strengthened by humanist ideas on work and diligence. ${ }^{27}$ The opposition of diligence to idleness was a central theme in humanist thought on human virtues and vices. From i 550 onward, labour became a means to acquire not just prosperity but also self-confidence and selfesteem, and to distinguish oneself from others. Idleness was considered the ultimate vice. ${ }^{28}$

In the sixteenth century, the representation of labour and diligence became extremely popular in Dutch art. According to Ilja Veldman, the work ethic stemmed from the development of an urban citizenry. The increasing independency of the individual, the impact of moral precepts to guide burghers in their everyday lives, and the influence of humanist ideas were factors that led to the development of the view that labour and diligence

22. Max Weber, The Protestant Ethic and the Spirit of Capitalism (New York, I930). See also Lis and Ehmer, "Introduction".

23. Wood, Medieval Economic Thought, p. 53; Birgit van den Hoven, Work in Ancient and Medieval Thought: Ancient Philosophers, Medieval Monks and Theologians and their Concept of Work, Occupations and Technology (Amsterdam, 1996).

24. Lis and Ehmer, "Introduction", pp. I3-I4; Ilja M. Veldman, "Representations of Labor and Diligence in Late-Sixteenth-Century Netherlandish Art: The Secularization of the Work Ethic", in Arthur K. Wheelock, Jr and Adele Seeff (eds), The Public and Private in Dutch Culture of the Golden Age (Newark, NJ, 2000), pp. I23-I40, I23-I 24.

25. Lis and Ehmer, "Introduction", p. I 8.

26. De Vries and Van der Woude, First Modern Economy, pp. I65-172, I72. See also Veldman, "Representations of Labor and Diligence", p. I23; Lis and Ehmer, "Introduction", p. I5.

27. Veldman, "Representations of Labor and Diligence", p. I33.

28. Ibid., p. I33; Annette de Vries, Ingelijst Werk. De verbeelding van arbeid en beroep in de vroegmoderne Nederlanden (Zwolle, 2004), p. 23. 
were a means of obtaining prosperity. ${ }^{29}$ This work ethic remained strong during the Golden Age. Humanists encouraged industriousness as a remedy for poverty, crime, and moral decay. But there was also a growing awareness of the economic importance of work, ${ }^{30}$ and it was increasingly perceived as a road to prosperity, as beneficial to both the individual and society as a whole. ${ }^{3 \mathrm{I}}$ Seventeenth-century mercantilism emphasized labour as a means to increase productivity. ${ }^{32}$ To Dutch mercantilist economists, work was a means to achieve wealth and to enhance one's social position, as Thomas Buchner has shown. ${ }^{33}$

In the eighteenth century, again, new attitudes to work emerged, but work continued to be valued highly. Productivity and the connection between work and economic progress were central in how eighteenth-century economists perceived work. ${ }^{34}$ Enlightenment philosophers emphasized work as fundamental to human self-realization. ${ }^{35}$ In implementing Enlightenment ideals, the elevating and educational effects of work were stressed. ${ }^{36}$

The meanings attached to "work" in Protestant, humanist, mercantilist, and Enlightenment thought differed, but all held work in high esteem, and in one way or another they all propagated industriousness. This prompts the question of how women fitted in to the ideology of work. After all, the positive evaluation of work, the often high esteem in which gainful employment was held, and the strict norms which required people to provide for their own subsistence by means of work seem to conflict with the narrowing gender roles that increasingly assigned the task of breadwinning to men and the private world and the household to women.

\section{WOMEN AT HOME, MEN ON THE STREET}

The association of women with the home was deeply rooted in European culture, but the advice to women to remain at home became a "clamouring chorus" in seventeenth-century Holland, as Elizabeth Honig put it. ${ }^{37}$ In Anthonis de Roovere's poem Van den binne tastere, published around I 55 ,

\footnotetext{
29. Veldman, "Representations of Labor and Diligence", pp. I23, I 38.

30. Jütte, Poverty and Deviance in Early Modern Europe, p. 198.

31. Veldman, "Representations of Labor and Diligence".

32. Farr, Artisans in Europe, p. 16.

33. Buchner, "Perceptions of Work in Early Modern Economic Thought".

34. Farr, Artisans in Europe, p. I 8; Cynthia J. Koepp and Steven Laurence Kaplan, "Introduction", in idem (eds), Work in France: Representations, Meaning, Organization and Practice (Ithaca, NY, 1986), pp. I3-53, I5; Lis and Ehmer, "Introduction", p. 20.

35. Lis and Ehmer, "Introduction", p. 8.

36. J.W. Spaans, Armenzorg in Friesland I 500-I 800: Publieke Zorg en Particuliere Liefdadigheid in Zes Friese steden: Leewwarden, Bolsward, Franeker, Sneek, Dokkum en Harlingen (Hilversum, I997), pp. 330, 365-366.

37. Elizabeth Alice Honig, "Desire and Domestic Economy", Art Bulletin, 83 (2001), pp. 294-315, 306.
} 
a peasant complains that he has to work so hard while his wife just stays at home, having a quiet and easy life. The couple decide to switch roles for one day. After having spent a day working hard in the field in the open air, the wife returns home, tired but satisfied. For the peasant, the day was less successful. He appeared unable to cope with the household chores and to take care of the animals and the young children at home. De Roovere's message is clear: each sex should stick to its own tasks, and the typical feminine responsibilities of attending to the household should not be underestimated..$^{3}$ The caricatures within the tradition of the reversed gender roles also assigned household tasks to women and outside work to men.

Presenting attending to the household as a typical feminine task was combined with the propagation of chastity as a feminine virtue. This ideal implied that women were supposed to remain at home. Desiderus Erasmus prescribed that women should leave their home as little as possible. At home, a woman would not be exposed to any seduction or bad company. ${ }^{39}$ Juan Luis Vives shared this opinion and in his influential De Institutione Feminae Christianae, a Dutch edition of which appeared in I554, stated that the advice not to appear too often in public was addressed especially to married women, as they had already found what non-married women were still looking for. ${ }^{\circ}$

A century later, when the Dutch Republic experienced an economic boom, women were still advised to stay at home as much as possible. Jacob Cats, author of the best-known and most widely disseminated conduct book of the seventeenth century Houwelick, dat is het gansche beleyt des echten-staets (I625), was very clear about gender roles: a husband must leave the house and practice his trade, a wife should stay at home and watch the kitchen. ${ }^{4 \mathrm{I}}$ For Cats the responsibilities of women lay first and foremost in attending to the household. Petrus Wittewrongel, clergyman and famous representative of the Further Reformation, the movement resembling English Puritanism, which desired to apply Reformation teachings to their day, claimed that it would not suit women to be seen too often in the open field or in public streets. It is not without reason, he argued in his Oeconomia Christiana (I655), that a woman is called a "housewife". ${ }^{22}$ Johan van Beverwijck had addressed the same issue in his Van de Wtnementheyt des vrowwelicken geslachts (1639) [On the Excellence of the Female Sex], one of

38. Bleyerveld, Hoe Bedriechlijck dat die Vrouwen zijn, p. I63; Kloek, Vrouw des huizes, p. I 5. 39. Arend V.N. van Woerden, Vrouwelijk en mannelijk bij Erasmus. Een onderzoek inzake genus (Rotterdam, 2004), p. 55.

40. Juan Luis Vives, Die Institutie en de Leeringe van een Christelijke Vrouwe (Antwerp, I554).

4I. Jacob Cats, Houwelick, dat is het gansche beleyt des echten-staets (Amsterdam, I625) p. 90. 42. Petrus Wittewrongel, Oeconomia Christiana ofte christelicke huys-houdinghe (Amsterdam, I655), p. 72 I. 
the most famous examples of appraisal literature on Dutch women. He argued that a woman's virtue consists primarily in keeping the household and that this was the very reason why married women "in our language" are called "housewives" (Huys-vrouwen). ${ }^{43}$ Both Wittewrongel and Van Beverwijck referred to the analogy of a housewife and the tortoise, the traditional emblem of female virtue, as this animal carried its house on its back and was therefore always at home.

Conduct books, works of household management, proverb collections, and moral treatises all urged women to stay at home. ${ }^{44}$ Yet these recommendations did not imply that women were not allowed to leave their homes at all. Women had to serve God and thus attend church, keep in contact with neighbours, and visit friends. Moreover, attending to the household would require them to leave home once in a while, and they might be taken out by their husbands. Even so, their prime responsibilities lay in the home, and the household required their continuous attention.

The idea that women were better suited to running the household than men was substantiated by references to the Bible and to women's physical characteristics. Luther claimed, for example, that women have a small chest, broad hips, and a broad seat; broad hips facilitate childbirth; and a broad seat indicates that they should keep seated and not leave the home. ${ }^{45}$ Van Beverwijck too referred to the female anatomy. Physically, women were of a more delicate design, their flesh was softer, and their muscles weaker because women would fulfil their duties within the house. Men, on the contrary, could withstand coldness, heat, and travelling and were thus, according to the medical doctor, better equipped for outdoor activities. ${ }^{46}$ Therefore, all work outside the house was assigned to men, and work that could be done inside the home was assigned to women. ${ }^{47}$

\section{INDUSTRIOUSNESS AND THRIFT}

Sixteenth- and seventeenth-century writers assigned work outside the home to men and inside the home to women. But what tasks were women supposed to fulfil? Women were in charge in the home. A housewife had to ensure that her orders would be acted upon, and, furthermore, she should dedicate her time to cleaning the house, washing clothes, preparing food, raising children, and instructing and managing her servants, if she had any. Spinning, making and mending clothes, and other textile chores

43. Johan van Beverwijck, Van de Wtnementheyt des vrowwelicken geslachts (Dordrecht, I639), p. 206.

44. Honig, "Desire and Domestic Economy", p. 306.

45. Gunning, Gewaande rechten, p. 88.

46. Van Beverwijck, Van de Wtnementheyt des vrouwelicken geslachts, p. 207.

47. Ibid., p. 205 . 
were also considered household chores. ${ }^{48}$ Erasmus advised girls to learn spinning and weaving. The seventeenth-century poet Gillis Jacobs Quintijn instructed mothers to keep their daughters at home and ensure they were kept occupied in spinning, sewing, and lacemaking. ${ }^{49}$ Wittewrongel referred to spinning, making clothes, and work with wool and flax when he urged women to be continuously busy.

In the conduct literature of the sixteenth and seventeenth centuries, these activities were presented first and foremost as part of the household chores, as production for subsistence. However, if, Erasmus and Wittewrongel stated, a woman produced more than she needed for her household, the produce could be sold at the market. ${ }^{5 \circ}$ Dirck Volkertsz. Coornhert also included spinning among the "necessary and useful" means by which women could earn an income. ${ }^{5 \mathrm{I}}$ It took until the eighteenth century, however, before these "feminine handworks" were more explicitly presented as honourable income-earning activities. ${ }^{52}$

Even though women acted as producers, for a long time they were associated more with consumption than with production. In his poem "Men behoeft veel die huijs sal houwen" (I 524) [One Needs a Lot to Keep up a Home], Jan van Stijevoort emphasized the feminine virtue of thrift by criticizing the squandering behaviour of a housewife who shouts to her husband "Provide or find money in public so that I can buy". ${ }^{53}$ If a woman wanted to contribute to the economy of the household - and it was her duty to do so - she was obliged in the first instance to run the household thriftily, as Vives asserted. ${ }^{54}$ Seventeenth-century writers also appealed to the role of women as consumers and men as producers. Van Beverwijck referred to Aristotle when he recalled that men should obtain the goods and women preserve them. ${ }^{55}$ Wittewrongel urged married women to be economical, as what a man brought in should be used by her thriftily. ${ }^{56}$

48. Ibid., p. 207; Van Woerden, Vrouwelijk en mannelijk bij Erasmus, p. 55.

49. Cited in E.M. Kloek, "De Vrouw", in H.M. Beliën, A.T. van Deursen, and G.J. van Setten (eds), Gestalten van de Gouden Eeuw. Een Hollands Groepsportret (Amsterdam, 1995) pp. 24I-279, 254.

50. Van Woerden, Vrouwelijk en mannelijk bij Erasmus, p. 56. Wittewrongel, Oeconomia Christiana, p. 723 .

51. De Vries, Ingelijst werk, p. 232.

52. J. le Francq van Berkhey, Natuurlyke historie van Holland, 9 vols (Amsterdam, I769-I 8 I I), pp. I 320-I 32 I. See also Danielle van den Heuvel, Women and Entrepreneurship: Female Traders in the Northern Netherlands, c.I580-I8Is (Amsterdam, 2007), pp. 44-45.

53. Frederik Lyna and Willem van Eeghem (eds), Jan van Stijevoorts Refereinenbundel anno I524 (Antwerp, n.d.), p. I59, available at http://www.dbnl.org/tekst/stijooIrefeor/stijoo r refeoI_ 2I 2. htm\#Ni45O.

54. Vives, Die Institutie en de Leeringe, cap IX.

55. Van Beverwijck, Van de Wtnementheyt des vrouwelicken geslachts, p. 207.

56. Wittewrongel, Oeconomia Christiana, p. 724. 
Sixteenth- and seventeenth-century conduct literature was usually addressed to married women and prepared women for their ultimate calling in life: marriage. But what advice was given to women who were not married? Moralists were usually not very explicit about the matter. Unmarried women were usually referred to as women who were not yet married. We have already seen that Vives considered it more important for married women to remain at home than for single women to do so. Nonetheless, this did not imply that unmarried women were permitted to manifest themselves in public too loudly and prominently. Erasmus too argued that single women would be better off staying at home than wandering around. As far as widows were concerned, they were supposed to replace their husband as responsible household heads and dedicate their time to the upbringing of their children. ${ }^{57}$ In the debate about the question of whether women were capable of learning, Anna Maria van Schurman had argued as early as I638 that women who were exempt from household tasks had the right, even the obligation, to develop their intellectual potential and to dedicate their time to intellectual work. ${ }^{58}$

Although moralists did not encourage women to work for profit, it was not presented as problematic in literary or visual representations. As Annette de Vries has pointed out in her essay on the visual representation of labour and diligence, in the anonymous seventeenth-century painting De strijd om het dagelijks brood [Struggle for Daily Bread] women were also depicted among the representatives of different crafts and trades struggling to earn their daily bread..$^{59}$ In the middle, two women with spindles can be discerned, apparently just as dedicated as the men to winning the struggle. ${ }^{60}$ In conduct books that taught women to be good housewives, working women figured too without any further explanation apparently having to be given.

Working women also appear in Cats's work. The depictions of the lacemaking girl and sewing widow that decorate the cover page of Houwelick probably represent household tasks. ${ }^{61}$ But Cats also wrote poems about milkmaids and fishwives, who obviously worked for pay outside the house. ${ }^{62}$ When, in his Lof der vrouwen (I7II) [In Praise of Women],

57. Van Woerden, Vrouwelijk en mannelijk bij Erasmus, p. I32; Ariadne Schmidt, Overleven na de dood. Weduwen in Leiden in de Gouden Eeuw (Amsterdam, 200I), pp. 44-45.

58. Mirjam de Baar, "Schurman, Anna Maria van", in Digitaal Vrouwenlexicon van Nederland, available at: http://www.inghist.nl/Onderzoek/Projecten/DVN/lemmata/data/Schurman,\% 20Anna \% 20 Maria\% 2ovan; Kloek, Vroww des huizes, p. 76.

59. Annette de Vries, "Toonbeelden van huiselijkheid of arbeidzaamheid? De iconografie van de spinster in relatie tot de verbeelding van arbeid en beroep in de vroegmoderne Nederlanden", Tijdschrift voor Sociale en Economische Geschiedenis, 2 (2005), pp. 103-I 25 , I I 8.

60. De Vries, Ingelijst werk, p. 23 I.

61. Idem, "Toonbeelden van huiselijkheid of arbeidzaamheid?", p. i I6.

62. Jacob Cats, "Invallende gedachten op voorvallende gelegentheden", in idem, Alle de wercken (Amsterdam, 1700), pp. 393-394. 


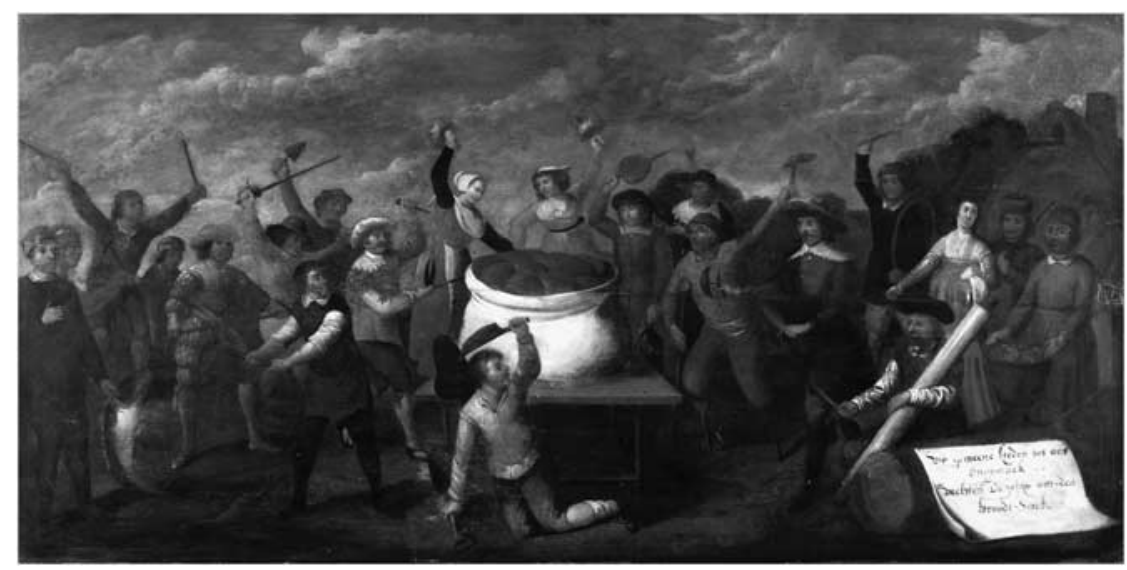

Figure I. Women depicted with spindles.

Printed in Anonymous, The Struggle for Daily Bread, I600-1650. Amsterdam Museum. Used with permission.

Jan van Gijsen fiercely defended the hard-working women of Amsterdam in response to an anonymous satirical work on women, he mentioned the female street vendors who walked down the streets and "carried, hauled, and wheeled" wagons full of fruit, vegetables, herring, and haddock, trying to sell their merchandise. ${ }^{63}$

Van Beverwijck, who advised women to stay home and dedicate their time to the household, did not imply that women were capable solely of doing housework. In his Van de Wtnementheyt, one of most famous Dutch examples of the tradition of appraisal literature on women, he reminds us that, without neglecting their households, many Dutch women were involved in crafts and trades ("nering ende koopmanschap") and others in arts and sciences. ${ }^{6}$ Likewise, in his Swart register van duysent sonden (I679) [Blacklist of a Thousand Sins] the clergyman Jacobus Hondius fiercely criticized gadabout women. A virtuous woman ought to stay at home and look after the household, unless her occupation required her to leave the house often and she had to earn a living.

Moreover, despite the strict advice to women to dedicate themselves to housework, throughout the book a whole range of female occupations are mentioned without any further comment. Hondius, for example, forbade female mattress-stoppers, female knitters, domestic servants, female soulsellers, seamstresses of linen, seamstresses of wool, and female knitters of fishing nets to carry out their regular work on Sundays. Implicitly, therefore,

63. Jan van Gijsen, Lof der vrouwen of weederlegging tegens het Leven van de hedendaagse vrouwen (Amsterdam, I7II), p. 4.

64. Van Beverwijck, Van de Wtnementheyt des vrouwelicken geslachts, p. 2 I I. 
it was allowed on the remaining six days of the week. Bosses, masters, and mistresses had to do their utmost to teach their apprentices a craft. Midwives were urged to attend to women in childbirth and unborn babies with care and shop girls were told to be loyal to their "Boss or Mistress". ${ }^{65}$ Even though in the seventeenth century widows were considered deserving recipients of poor relief, Hondius urged them to first try to find a means of subsistence and maintain themselves before seeking poor relief. ${ }^{66}$

Abundant examples of working women in conduct books urged women to be diligent and industrious. In doing so, these literary works linked up with a theme propagated in the visual arts as well. With her reinterpretation of the depiction of female spinners, who represent the virtue of female diligence rather than of domesticity, Annette de Vries has shown that diligence, and not domesticity as such, was at the core of female virtuousness. Hard work would prevent not only men but also women from all kinds of vice - in the first place the vice of idleness - just as spinning in the spinning houses that mushroomed in the eighteenth century was supposed to be the right remedy to lead "disorderly" women back on the track of a virtuous life. ${ }^{67}$

The theme of the diligence of Dutch women had a long tradition and probably dates back to Tacitus (AD 55-I20), who, in his Germania, described Batavian men as idle and women as industrious. ${ }^{68}$ In the early modern period this theme was taken up and diligence became celebrated as a feminine virtue. The sixteenth-century conduct books by Erasmus and Vives praised the industriousness of Dutch women, many of whom were said to be active in trade and even maintained their husbands as the latter were too idle to work. ${ }^{6}$ Wittewrongel urged women to work continuously. Women could work harder than men, he claimed: men go to work after sunrise, as their outdoor activities require sunlight. But as women work inside the house, they could light a candle and thus start work early, as early even as in the night. ${ }^{70}$

The connection of diligence with paid work was also still prevalent in seventeenth-century discourse. But this time, the connection with work inside the home was not made. Cats praised milkmaids and fishwives, who were said to work harder than domestic servants. ${ }^{7 \mathrm{I}}$ That they worked outside the home is obvious. Grotius took up the familiar theme in his

65. Jacobus Hondius, Swart register van duysent sonden (Amsterdam, 1679), nos. 42, 46, I44, $336,4 \mathrm{I} 4,804,959,968$, and 989 .

66. Schmidt, Overleven na de dood, pp. I79-180; Hondius, Swart register van duysent sonden, no. 983 .

67. De Vries, “Toonbeelden van huiselijkheid of arbeidzaamheid?”, pp. 103-125.

68. Kloek, Vrouw des huizes, pp. 28-30.

69. Ibid.

70. Wittewrongel, Oeconomia Christiana, p. 722.

7I. Cats, "Invallende gedachten op voorvallende gelegentheden". 
Vergelijking der gemeenebesten (1603) and attributed the affluence of the Dutch to the involvement in trade of both women and men. Women raised children, cared for the household, and at the same time took part in trade when their husbands were absent: they administered capital, sold goods, kept accounts, and travelled back and forth without putting their dignity and chastity at risk. ${ }^{72}$ That the reputation of Dutch women as hardworking entrepreneurs was widely known is shown by the large body of literature written by foreign visitors commenting upon their prominent involvement in commercial activities. ${ }^{73}$ And, again, these women must have worked in public places, as their industriousness would otherwise have remained unnoticed by the commentators.

Seventeenth-century Dutch economic theorists either neglected female work or regarded it as of minor importance for the wealth of a society, as Thomas Buchner has shown. ${ }^{74}$ Josiah Child, the English merchant and proponent of mercantilism, apparently formed an exception. In his A New Discourse of Trade, first published in 1668, he wrote:

The Education of their Children, as well Daughters as Sons; all which, be they of never so great Quality or Estate, they always take care to bring up to write perfect good Hands, and to have the full knowledge and use of Arithmetick and Merchants Accounts; the well understanding and practice whereof, doth strangely infuse into most that are the owners of that quality, of either Sex, not onely an Ability for Commerce of all kinds, but a strong aptitude, love, and delight in it; and in regard the Women are as knowing therein as the Men, it doth incourage their Husbands to hold on in their Trades to their dying days, knowing the capacity of their Wives to get in their Estates, and carry on their Trades after their Deaths. ${ }^{75}$

Writers of seventeenth-century household manuals acknowledged the importance of the labour of women to the household economy, and both Dutch and foreign observers acknowledged the importance of their efforts for the common good. In the eighteenth century, however, ideas about gender roles changed. Whereas sixteenth-century humanists had told women to stay at home and dedicate their time to the household, the eighteenth-century advice literature taught women that it was their responsibility to create an atmosphere of homeliness in which a father could fulfil his role as breadwinner and where children could be raised. Prescriptive works more explicitly excluded married women from the public sphere. The role of a woman as mother, wife, and homemaker

72. Els Kloek, "De Geschiedenis van een Stereotype: De Bazigheid, Ondernemingszin en Zindelijkheid van Vrouwen in Holland (I 500-1800)", Jaarboek Centraal Bureau voor Genealogie, 58 (2004), pp. 5-25, I 2.

73. Ibid.; Van den Heuvel, Women and Entrepreneurship, pp. 40-43.

74. Buchner, "Perceptions of Work in Early Modern Economic Thought", p. 2 I 2.

75. Josiah Child, A New Discourse of Trade, Wherein is recommended several weighty Points relating to Companies of Merchants etc. (London, I698), p. 4. 
became celebrated. ${ }^{76}$ That she was supposed to raise the children and manage the household was stressed even more than before - at least in literature.

\section{GENDER NORMS IN DAILY PRACTICE}

The humanist message about the virtue of diligence was diffused not just throughout north-western Europe in the arts. It also reached a broad public with its ideas on social welfare. Social and political unrest, economic decline, increased migration, and urbanization all increased concerns about poverty. Humanist views changed the perception of poverty and inspired the reorganization of municipal poor relief in the sixteenth century. The emphasis on diligence was one of the key themes in sixteenth-century projects to reorganize poor relief. ${ }^{77}$

In the most famous treatise on the subject, De Subventione Pauperum (I 526) [On Assistance to the Poor], Juan Luis Vives distinguished between the idle and the deserving poor, advocated civic supervision of all poor relief, and the employment of those who were fit and healthy. ${ }^{78}$ Like other humanists, such as Bucer and Melanchton, Vives also strongly advocated education as a remedy to combat idleness and discipline the poor. ${ }^{79}$ In his recommendations for publicly supported schools for children Vives made no exception for girls, as he argued in favour of "a similar school for girls, in which they could be taught the fundamentals of literacy", and even claimed that if a "girl is particularly qualified for studies and is inclined to them, she should be permitted to progress farther, provided that the courses coincide with the development of her character" ${ }^{80}$ Dirck Volkertsz. Coornhert too believed that employment was the remedy for beggary and vagabondage and suggested that the poor should be put to work: men could be employed by artisans, women and girls should be put to work spinning and weaving. ${ }^{81}$

The humanist perceptions of poverty that inspired the reorganization of poor-relief systems in several countries also resonated in the programmes to reform public assistance in various Dutch towns: begging was prohibited, the healthy poor were employed, their children were educated, and public assistance for the undeserving poor was restricted. ${ }^{82}$

76. Sturkenboom, Spectators van Hartstocht, pp. 327-333.

77. S. Groenveld, J.J.H. Dekker, and T.R.M. Willemse, Wezen en boefjes. Zes eeuwen zorg in wees- en kinderbuizen (Hilversum, 1997), pp. 21-22; Spaans, Armenzorg in Friesland, p. 40. 78. Jütte, Poverty and Deviance in Early Modern Europe, pp. 21 5-216.

79. C. Lis, H. Soly, and D. Van Damme, Op vrije voeten? Sociale politiek in West-Europa (1450-1914) (Leuven, 1985), p. 62.

80. Juan Luis Vives, On Assistance to the Poor [with an introduction by Alice Tobriner] (Toronto, I999), p. 43.

81. Spaans, Armenzorg in Friesland, pp. 83-85.

82. Ibid., p. 43. Groenveld, Wezen en boefjes, pp. 2 I-24. 
In his 1577 treatise on the reorganization of poor relief, the Leiden secretary Jan van Hout, for example, also distinguished between the idle and what were considered the "honourable poor", those people who were not to blame for their poverty. He mentioned women in childbed, the sick, widows, and "poor people burdened with children" as deserving recipients of public support. These people were apparently not considered able to maintain themselves through work. It is significant that women were not mentioned as a separate category. ${ }^{83}$ Apparently, healthy women who were not pregnant were supposed to work. In practice, public assistance was considered as an additional source of income for both women and men, and a request for support was legitimized only if one was unable to work or if one's earnings were insufficient. ${ }^{84}$

In the Dutch Republic, as in most other countries in north-western Europe, the intellectual debate on poverty resulted in the employment of vagabonds and the poor. Inspired by Coornhert, work became a central element in the punishment of criminals in the houses of correction established in Dutch cities in the late sixteenth and seventeenth centuries. By providing work, the authorities tried to stimulate the work ethic and teach prisoners a trade to facilitate their rehabilitation. In practice, it appeared difficult to implement these ideals, and punishment became more important than vocation. But inmates of both sexes were set to work, as women had to spin and men to rasp in these institutions. ${ }^{85}$

The need to provide work to the poor and vagabonds also resulted in the establishment of workhouses from the late sixteenth century onward. ${ }^{86}$ The meaning of work in these institutions shifted gradually. In the seventeenth century workhouses were established to provide employment to combat poverty and beggary; in the eighteenth century humanist ideals were replaced by enlightened perceptions of work. Workhouses too came to be seen as instruments for moral discipline, education, and elevation. ${ }^{87}$

83. J. Prinsen, "Armenzorg te Leiden in 1577 ", Bijdragen en mededelingen van het Historisch Genootschap, 26 (1905), pp. I I3-160, I54-155.

84. Hilde van Wijngaarden, Zorg voor de kost. Armenzorg, arbeid en onderlinge bulp in Zwolle I650-1700 (Amsterdam, 2000), p. I34; Ingrid van de Vlis, Leven in armoede. bedeelden in de zeventiende eeuw (Amsterdam, 200I), p. I79.

85. P. Spierenburg, "The Sociogenesis of Confinement and its Development in Early Modern Europe", in idem (ed.), The Emergence of Carceral Institutions: Prisons, Galleys and Lunatic Asylums, I550-1900 (Rotterdam, 1981), pp. 9-77, 24-42; Spaans, Armenzorg in Friesland, pp. $85-86$.

86. Farr, Artisans in Europe, pp. I4-I s; Jütte, Poverty and Deviance in Early Modern Europe, p. 169.

87. Spaans, Armenzorg in Friesland, pp. 330, 339-340; H.F.J.M. van den Eerenbeemt, Armoede en Arbeidsdwang: Werkinrichtingen voor "onnutte" Nederlanders in de Republiek, 1760-1795: Een Mentaliteitsgeschiedenis (The Hague, I977), p. 33. 
Alongside philanthropic and moral intentions, economic motives too came to play a role in the employment of workhouse inmates. ${ }^{88}$ The authorities recognized the productive potential of forced labour, and work in workhouses was regarded as a contribution to the development of manufactories. ${ }^{89}$ In the eighteenth century, by employing the inmates of workhouses, local authorities and private entrepreneurs hoped to revitalize the industrial sector, which had been so important for the economic prosperity of the Golden Age but which had declined since the late seventeenth century. Production based on the processing of domestic raw materials should furthermore substitute the import of foreign goods. ${ }^{9}$ Women were not excluded as a category from these different perceptions of work. Workhouses provided hemp, flax, and wool to poor women so that they would be able to earn something from spinning, and workhouses often chose to employ their inmates in one of the sectors of the textile industry as this was work that was thought to be suitable for women as well. $9^{\mathrm{I}}$

Practices in court also demonstrate that women were expected to maintain themselves and their children through paid work. Women who were summoned to court and confined because of theft were often introduced as being "strong, young, and brave" enough to "earn a living with their own hands". ${ }^{2}$ Their ability to work - their physical strength made their crime even more serious.

Women were supposed to work for their own subsistence, and this was the norm not just for the poorest among the female population. The issue of responsibility for maintaining a family came to the fore when marriages were dissolved. When marital conflicts became irresolvable, a marriage could be legally dissolved. Lawyers agreed that a wife could be awarded a maintenance allowance after separation from her husband if she was at least unable to maintain herself on income from capital or work. After all, a legal separation still implied that the husband and wife were legally married, in which case, it was argued, the man was obliged to continue to maintain his spouse. Apparently, however, this was a reciprocal obligation, as women could also be forced to pay a maintenance allowance to their former husbands. This happened, for example, when the children were assigned to the father because the mother was to blame for the separation.

88. Jütte, Poverty and Deviance in Early Modern Europe, p. 198; Farr, Artisans in Europe, pp. I 5 -I 6 .

89. Farr, Artisans in Europe, pp. I $5-16$.

90. Van den Eerenbeemt, Armoede en Arbeidsdwang, pp. 33-34; Spaans, Armenzorg in Friesland, pp. 354-361; Elise van Nederveen Meerkerk, De draad in eigen handen. Vrouwen en loonarbeid in de Nederlandse textielnijverheid I58I-I8I0 (Amsterdam, 2007), pp. I77-179.

91. Spaans, Armenzorg in Friesland, p. 340; van den Eerenbeemt, Armoede en Arbeidsdwang, p. 33. 92. See for example Rijksarchief Leiden (RAL), Oud Rechterlijk Archief (ORA), 3, 5, passim. 
This practice illustrates the fact that in the early modern period maintenance allowances were intended in the first instance for the maintenance of children, not as a provision for women. Only i 2 per cent of divorced women received a maintenance allowance for themselves. It was not asked for very frequently, not even by women from the upper or middle classes, who might be assumed to have been less likely to perform paid work. ${ }^{93}$

The maintenance allowance, often paid weekly or annually, was usually rather low and insufficient to sustain a family. It is significant that in a very few cases women were even assigned the business the couple had previously run together as a form of maintenance allowance. Moreover, the examination of thousands of cases of separation and divorce by Dini Helmers has revealed that women never supported their request for maintenance by arguing that it would be "indecent" for them to work. Most people could probably not afford to put forward such an argument, and it is highly unlikely that all these working women would have been considered "indecent". ${ }^{4}$

The concept of the male breadwinner is very much associated with the rise of capitalism and often considered an invention of the nineteenth century. ${ }^{95}$ The ideal of the male breadwinner existed earlier, though. The widow Jannetgen Gillis petitioning Leiden's city council in 1646 for support as she, a "sad widow", had lost "her beloved husband and breadwinner" ["haren welbeminden man ende brootwinner"] is a rather early reference to the notion of the male breadwinner, but not the only one. ${ }^{96}$ That a married man had to be able to maintain his family was a frequently used argument in conflicts between parents and children on the choice of marriage partner, as Manon van der Heijden has noted.

Legally, only minor children, those under the age of twenty-five, needed their parents' consent to marry; for those of age, the consent of their parents was desirable nonetheless. In seventeenth-century Holland the most common reason put forward by parents for withholding their consent to the marriage of their daughters was that they were not convinced that the intended spouse would be able to support a family. Girls' parents might object to his lack of experience or skill, and some required that a bridegroom first pass his examinations before they would consent to the marriage. Married women were also expected to contribute to the

93. D. Helmers, "Gescheurde bedden." Oplossingen voor gestrande huwelijken, Amsterdam I753-I8I0 (Hilversum, 2002), pp. 257-262, 264.

94. Ibid., p. 263.

95. Angélique Janssen, "The Rise and Decline of the Male Breadwinner Family? An Overview of the Debate", in idem (ed.), The Rise and Decline of the Male Breadwinner Family?, International Review of Social History, Supplement, 42 (1997), pp. I-23.

96. Ariadne Schmidt, "Survival Strategies of Widows and their Families in Early Modern Holland, c.1580-1750", History of the Family, I 2 (2007), pp. 268-28 I, 268. 
household economy. But the skills of potential brides were never mentioned, and the economic contribution of the prospective wife was rarely questioned by the parents of the bridegroom.

Even so, the inability to maintain a family was not necessarily an insurmountable impediment to marriage. For church councils, which had an important say in matrimonial affairs, financial objections were not accepted as valid reasons to break marriage vows. For magistrates too, who ultimately decided on marital issues, the ability to keep a family was not of decisive importance in the choice of marriage partner. ${ }^{97}$

Due to the growing wage dependency of men in the course of the seventeenth century, many women were confronted with a loss of income after the death of a spouse. Structural solutions in the form of guaranteed benefits provided by guilds or state pensions did not yet exist. In the course of the seventeenth century various social groups began to develop new and specialized forms of support for their widows, and these initiatives might be interpreted as an indication of the growing importance of the ideal of the male breadwinner.

Clergymen were the first group within society to propose comprehensive arrangements for the maintenance of their widows. Provisions for clergymen's widows had been identified as a point of concern at the national synod in I $88 \mathrm{I}$. At the end of the sixteenth century, the church authorities tried to find a solution for the loss in income suffered by the widows of clergymen. Local religious communities were advised to establish mutual assistance funds, but owing to lack of finance such local initiatives could not be realized everywhere. Initiatives at provincial level were more successful from the i 590 s. In large parts of the province of Holland, widows of clergymen were paid an annual pension of 50 guilders, and later of between 100 and 250 guilders. These payments were inadequate to compensate for the income loss sustained by those widows, as the average clergyman's stipend had increased considerably since the end of the sixteenth century and by the second half of the seventeenth century annual stipends of 600-800 guilders were not uncommon. These initiatives nevertheless demonstrate the awareness of the vulnerability of widows, and underline the fact that men were considered responsible for maintaining their families, even after their deaths..$^{8}$

It is probably no coincidence that the first pensions were established for the widows of clergymen, as they functioned as role models in the period so soon after the Reformation. During the provincial synod of Holland

97. Manon van der Heijden, "Contradictory Interests: Work and Parent-Child Relations in Early Modern Holland", History of the Family, 9 (2004), pp. 355-370, 359-36r.

98. A. Schmidt, “'Dat oock de Weduwen ende Weesen der Dienaren niet vergethen werden': de Ontwikkeling van de Zorg voor Predikantsweduwen in Leiden in de Zeventiende Eeuw", Leids Jaarboekje (Leiden, 2000), pp. 38-53. 
in I 574 , the church authorities tried to restrict the work options of clergymen's wives to certain occupations: they were forbidden to engage in a public trade ["openbare- of winkelnering"]. Twenty years later the regulation was relaxed somewhat, although clergymen's wives who wanted to trade still had to ask permission first as some occupations were considered dishonourable. Church councils were instructed to be aware that clergymen's wives should not undertake professional activities that would dishonour them. Moreover, the general opinion of the authorities was that church councils should ensure that clergymen's stipends were sufficient to maintain a family. This ideal, however, did not correspond with the reality, as stipends were still rather low relative to the social standing of clergymen. An increase in stipends remained an important issue for the Reformed Church well into the seventeenth century. ${ }^{99}$

Arrangements for widows were especially popular in those sectors in which women's access to work was somehow restricted. After the Reformation, the informal mutual assistance of guild members developed into more formalized and regulated assistance in the form of mutual trade-based funds. Some, though by no means all, of these support funds used to provide pensions for widows in addition to assistance in meeting burial costs and support in the event of illness or old age. ${ }^{100}$ Bargemen, for example, used to provide for their widows as early as the beginning of the seventeenth century. For a limited period, newly appointed bargemen were required to pay some of their earnings to the widows of their predecessors to compensate them for loss of income. Widows of journeymen bargemen were recompensed from the journeymen's support fund, as were the widows of the journeymen brewers, who received modest weekly allowances. ${ }^{\text {IOI }}$ In 1666 bargemen from Leiden to Utrecht even supported the establishment of widows' funds, stating explicitly that an honourable father and husband ought to provide for his wife and children, and in particular for his widow. ${ }^{102}$

The early statutes of transport guilds in Holland mention female members, and indirect evidence indicates that widows were admitted until well into the seventeenth century. ${ }^{103}$ During the course of the seventeenth century, however, women in the transport sector lost this privilege. Widows' pensions were not very common, because their potentially extended duration made them rather expensive. However, it is significant

99. Schmidt, Overleven na de dood, pp. 196-197.

Iо०. Sandra Bos, "Uyt liefde tot malcander": Onderlinge Hulpverlening binnen de NoordNederlandse Gilden in Internationaal Perspectief (I570-I 820) (Amsterdam, 1998), pp. 344-345. IоI. Schmidt, Overleven na de dood, pp. 206-207.

I02. Ibid., p. 208.

I03. Martha Hulshof, "De gilden", in Koen Goudriaan et al. (eds), De gilden in Gouda (Zwolle, 1996), pp. 87-148, 100. 
that in the transport sector the payment of small allowances to widows seems to have replaced the older practice of widows carrying on the work of their husbands, a practice still widespread among other craftsmen and tradesmen. ${ }^{\mathrm{IO}}$

From the second quarter of the eighteenth century onward, many voluntary widows' funds were established. The first private general widows' and orphans' fund was founded in Middelburg in I735, soon followed by similar funds in Leiden and Haarlem. These private initiatives, which were mainly concentrated in the large urban centres of Holland, were established not so much to meet the needs of poor widows as to avoid widows facing a lower standard of living after the deaths of their spouses. The funds were not successful. Most soon went bankrupt as provision for widows was extremely expensive and the actuarial knowledge necessary to ensure their survival was applied improperly. ${ }^{\text {105 }}$

The social polarization seen in the eighteenth century and the growing social insecurity contributed to an increased concern for one's personal reputation, since this could be threatened by a possible descent into poverty. But it is likely that, combined with the increased dependency on income from wage work, the male breadwinner ideology also contributed to the development of specialized financial provisions for widows among certain groups of urban society. It is important to stress that the establishment of widows' pensions could simply be seen as an indication of the spread of the ideal of the male breadwinner. We may assume that its impact on the actual labour-force participation of women was negligible as the twenty-one mutual widowhood insurance schemes that existed in I 800 covered less than I per cent of the total population. ${ }^{\text {I06 }}$

\section{CONCLUSION}

The ideology of domesticity that identified women with a domestic role became more articulated throughout the early modern period. Dutch society is said to have played a pioneering role in the development of this middle-class concept. The popular genres of conduct books, works of household management, collections of proverbs, and moral treatises all

I04. Schmidt, Overleven na de dood, pp. 206-208.

I05. Sandra Bos and Ida H. Stamhuis, "Begrafenis- en weduwenfondsen, en prebende sociëteiten", in Jacques van Gerwen and Marco van Leeuwen (eds), Studies over zekerbeidsarrangementen. Risico's risicobestrijding en verzekeringen in Nederland vanaf de Middeleeuwen (Amsterdam, 1998), pp. 175-182.

I06. Marco H.D. van Leeuwen, "Historical Welfare Economics from the Old Regime to the Welfare State: Mutual Aid and Private Insurance for Burial, Sickness, Old Age, Widowhood, and Unemployment in the Netherlands during the Nineteenth Century", in B. Harris and P. Bridgen (eds), Charity and Mutual Aid in European and North America since I 800 (New York, 2007), pp. 89-130, 107. 
urged women to remain in the home and indicate a narrowing of gender norms. Yet, at the same time, the early modern period was characterized by profound changes in the perception of work. Protestant, humanist, mercantilist, and Enlightenment thought shared a high esteem for work and propagated industriousness. These seemingly contradictory tendencies of narrowing gender norms and the positive evaluation of work prompt the question of how women fitted in with the early modern ideology of work. How did a society like the Dutch Republic, with its high standard of living and high labour productivity, reconcile the positive evaluation of work and the strict norms that required people to provide for their own subsistence with the restricted gender roles?

A closer examination of the sixteenth- and seventeenth-century debates on the role of women and the ideology of work, the practical advice given to women, and representations of work in literary publications (and the visual arts) reveals that in the early modern northern Netherlands labour was indeed valued positively and that in this respect no exception was made for women's work. The propagation of a work ethic by religious reformers and humanists did not conflict with gender norms that prescribed that women should dedicate their time to household tasks. The abundance of examples in conduct books and paintings of women figuring as craftswomen or merchants, spinners, weavers, lacemakers, knitters of wool or fishing nets, mattress-stoppers, domestic servants, soul-sellers, seamstresses of linen or wool, midwives, shop girls, and mistresses emphasized that women should be diligent. Industriousness was propagated as a virtue for both women and men. Men, but also women, ought to be diligent, and even though women's involvement in remunerated work was not encouraged in the didactic literature, nor - and that is even more remarkable - was it considered problematic.

This paradox can be solved by looking at the perception of work, which is highly gendered. Whereas nowadays we perceive of remunerated work and unpaid household work as being two separate categories, writers of conduct literature made no sharp distinction between work for subsistence (or the household) as women's work and paid work for the market economy as men's. Instead, they drew a dividing line between work within the home, which was regarded as women's work, and work outside the home, which was regarded as men's work. Women were advised to remain inside. Their responsibilities lay primarily in running the household - a rather comprehensive task in the early modern period, which included not only household chores but also feminine handwork. However, categories were never rigid. When a woman's diligence resulted in a surplus of produce, or if economic need forced her to do so, her work could be extended to include production for the market too.

Industriousness was propagated because, in the first place, it was thought to prevent women from the ultimate vice of idleness. The opposition of 
diligence to idleness became central in humanist thinking on human virtues: labour was perceived not only as a means of acquiring prosperity but also of self-confidence and self-esteem. In everyday life, however, industriousness also served a more practical purpose. The craftswomen, merchants, spinners, knitters, domestic servants, seamstresses, midwives, and shop girls had to be industrious because they had to earn their own living.

This brings us to the differences between the gender norms as presented in literary works and the norms with which people were confronted in everyday life. The often heard argument that a husband was supposed to be able to maintain his family, seventeenth-century examples of widows referring to the loss of their family's "breadwinner", and the more general search for structural solutions to the financial need of widows in the form of guaranteed benefits provided by guilds or state pensions are three examples indicating the growing popularity of the ideal of the male breadwinner. However, the influence of such norms on the actual lives of working women is another story. In practice, an explicit differentiation between different social groups of women had always been made.

The humanist message on the virtue of diligence directly influenced ideas about social welfare. Work was promoted as an instrument to combat poverty. Only those unable to work were excused and considered the legitimate recipients of public support. The gender norms embedded in and reproduced by institutions were clear: charity boards, criminal courts, local government, and church councils expected women to be able to maintain themselves. This implied that women from those social layers that lacked income from capital should provide for their own subsistence through work.

In literature, gender roles narrowed even more in the eighteenth century. The perception that men ought to maintain their families slowly trickled down to everyday life. References to the notion of the male breadwinner could be found in the seventeenth century and became more widely disseminated during the course of the eighteenth. Yet this ideal was realistic only for a small group of privileged women. In principle, society expected all able-bodied women to provide for their own maintenance by working. 